\title{
Filip MANIKOWSKI
}

Uniwersytet Kardynała Stefana Wyszyńskiego

\section{GLOSA APROBUJĄCA DO WYROKU NACZELNEGO SĄDU ADMINISTRACYJNEGO Z DNIA 6 PAŹDZIERNIKA 2016 R. O SYGN. AKT II GSK 2765/16}

Głosowany wyrok Naczelnego Sądu Administracyjnego (dalej: „NSA”) dotyczy problematyki refundacji leków sprowadzanych w trybie importu docelowego posiadających tzw. centralne pozwolenie na dopuszczenie do obrotu.

\section{Stan PRAWNy}

Słowem wstępu należy krótko scharakteryzować drogi, jakimi produkt leczniczy może znaleźć się w obrocie na terytorium Rzeczypospolitej Polskiej. Jedną z nich przewiduje art. 3 ustawy z dnia 6 września 2001 r. Prawo farmaceutyczne (Dz. U. z 2008 r. nr 45 poz. 271 z późn. zm., dalej: „Prawo farmaceutyczne”), zgodnie, z którym żeby produkt leczniczy mógł znaleźć się w obrocie, musi uzyskać pozwolenie na dopuszczenie do obrotu wydane przez Prezesa Urzędu Produktów Leczniczych, Wyrobów Medycznych i Produktów Biobójczych (tzw. narodowe dopuszczenie do obrotu) lub Radę Unii Europejskiej bądź Komisję Europejską (tzw. centralne dopuszczenie do obrotu). W pierwszym przypadku pozwolenie obejmuje obszar Rzeczypospolitej, natomiast w drugim wszystkie kraje członkowskie Unii Europejskiej. Odstępstwem od powyższej zasady jest art. 4 ust. 1 Prawa farmaceutycznego, stanowiący, 
że do obrotu bez konieczności uzyskania pozwolenia dopuszczone są leki sprowadzane z zagranicy, jeżeli ich zastosowanie jest niezbędne dla ratowania życia lub zdrowia pacjenta, pod warunkiem, że dany lek jest dopuszczony do obrotu w kraju, z którego jest sprowadzany i posiada aktualne pozwolenie dopuszczenia do obrotu (tzw. import docelowy). Lek sprowadzany jest na podstawie zapotrzebowania wystawianego przez szpital lub lekarza prowadzącego pacjenta potwierdzonego przez konsultanta $\mathrm{z}$ danej dziedziny medycyny. Powyższe zapotrzebowanie stanowi załącznik do rozporządzenia Ministra Zdrowia z dnia 21 marca 2012 r. w sprawie sprowadzania z zagranicy produktów leczniczych niezbędnych dla ratowania życia lub zdrowia pacjenta dopuszczonych do obrotu bez konieczności uzyskania pozwolenia (Dz.U. z 2012 r. poz. 349). Prawo farmaceutyczne w art. 4 ust. 3 wprowadza dodatkowe ograniczenia, zgodnie z którymi do obrotu w trybie importu docelowego nie mogą być dopuszczone leki, w stosunku do których wydano decyzję o odmowie wydania pozwolenia, odmowie przedłużenia okresu ważności pozwolenia, cofnięciu pozwolenia, jak również, co warto podkreślić, zawierających tę samą lub te same substancje czynne, tę samą dawkę i postać, co produkty lecznicze, które otrzymały pozwolenie. Wystąpienie powyższych okoliczności jest stwierdzane przez Ministra Zdrowia bezpośrednio na zapotrzebowaniu, co stanowi przesłankę do odmowy sprowadzenia leku.

W art. 4 ust. 9 Prawa farmaceutycznego przewidziano szczególny tryb importu docelowego. W powyższym trybie Minister Zdrowia może w przypadku klęski żywiołowej lub innego zagrożenia życia lub zdrowia ludzi wydać zgodę na sprowadzenie z zagranicy leku, który posiada pozwolenie na dopuszczenie do obrotu, o którym mowa w art. 3 Prawa farmaceutycznego, ale niedostępnego na terytorium Rzeczypospolitej. Tryb ten ma więc przede wszystkim zastosowanie do leków posiadających centralne dopuszczenie do obrotu, ale które $\mathrm{z}$ różnych powodów są niedostępne w Rzeczypospolitej. Należy bowiem zauważyć, że posiadanie centralnego pozwolenia na dopuszczenie do obrotu nie obliguje wytwórcy do jego faktycznego wprowadzania do obrotu na terytorium państw członkowskich, w tym również na terytorium Rzeczypospolitej. 
Z importem docelowym ściśle związany jest art. 39 ustawy z dnia 12 maja 2011 r. o refundacji leków, środków spożywczych specjalnego przeznaczenia żywieniowego oraz wyrobów medycznych (Dz.U. z 2016 r. poz. 1536, dalej: „Ustawa o refundacji”). Zgodnie z powyższym przepisem Minister Zdrowia może wyrazić zgodę na refundację leku nieposiadającego pozwolenia na dopuszczenia do obrotu sprowadzonego w trybie art. 4 Prawa farmaceutycznego. Minister Zdrowia działa na wniosek i w ciągu 30 dni wydaje decyzję, w której wyraża zgodę na refundację leku bądź jej odmawia.

Prima facie art. 39 Ustawy o refundacji nie wzbudza żadnych wątpliwości interpretacyjnych. Należy jednak zwrócić uwagę na dwa elementy, które występują w powyższym przepisie. Po pierwsze, odnosi się on do całego art. 4 Prawa farmaceutycznego, a zatem teoretycznie do wszystkich trybów sprowadzania leków tam wymienionych, a więc zarówno do ust.1, jak i ust. 9. Po drugie, dotyczy jedynie leków nieposiadających pozwolenia na dopuszczenie do obrotu. Oznacza to pewną sprzeczność, ponieważ jeżeli art. 39 ustawy o refundacji odnosi się do całego art. 4, to również do ust. 9 przewidującego możliwość sprowadzenia leku posiadającego pozwolenie na dopuszczenie do obrotu, lecz niedostępnego na terytorium Rzeczypospolitej. Literalna wykładnia art. 39 ust. 1 wyraźnie jednak wskazuje, że chodzi o leki nieposiadające pozwolenia na dopuszczenia do obrotu, a więc art. 39 nie może odnosić się do leków sprowadzonych w trybie art. 4 ust. 9 Prawa farmaceutycznego.

\section{STAN FAKTYCZNY}

Stan faktyczny w niniejszej sprawie nie budzi wątpliwości. Do Ministra Zdrowia wpłynął wniosek małoletniego reprezentowanego przez matkę w przedmiocie wyrażenia zgody na refundację produktu leczniczego we wskazaniu: dystrofia mięśniowa typu Duchenne’a w trybie art. 39 ust. 1 ustawy o refundacji. Wnioskodawca w swoim piśmie wskazywał, że istnieje potrzeba dokonania szybkiej refundacji, gdyż opóźnienie uniemożliwi zastosowanie leku, a ponadto podkreślał, że obecnie na rynku polskim nie jest dostępna żadna terapia alternatywna. 
Minister Zdrowia decyzją z 29 czerwca 2015 r. wydał zgodę na sprowadzenie z zagranicy produktu leczniczego zgodnie z zapotrzebowaniem zgłoszonym przez podmiot leczniczy załączonym do ww. wniosku, jednakże decyzją z 29 czerwca 2015 r. odmówił refundacji leku. Argumentacja organu oparta była na dwóch twierdzeniach. Po pierwsze, to podmiot leczniczy zgłaszający zapotrzebowanie na określony lek dla konkretnego pacjenta powinien ponieść koszty związane $\mathrm{z}$ taką terapią. Po drugie, organ nie mógł wydać zgody na refundację ww. produktu leczniczego w trybie art. 39 ust. 1 ustawy o refundacji, ponieważ wskazany przepis znajduje zastosowanie jedynie do produktów leczniczych nieposiadających pozwolenia na dopuszczenie do obrotu na terytorium Polski, tymczasem dla przedmiotowego leku wydano centralne pozwolenie na dopuszczenie do obrotu, które nie utraciło ważności.

Wnioskodawca złożył wniosek o ponowne rozpatrzenie sprawy, zarzucając naruszenie m.in. art. 7 , art. $77 \$ 1$ oraz art. $80 \mathrm{w} \mathrm{zw.} \mathrm{z} \mathrm{art.}$ $107 \$ 3$ ustawy z dnia 14 czerwca 1960 r. - Kodeks postępowania administracyjnego (Dz.U. Nr 30, poz. 168, dalej „k.p.a.”) polegające na niewyjaśnieniu wszystkich istotnych okoliczności dla prawidłowego rozstrzygnięcia sprawy, art. 10 ust. 2 pkt 2 w zw. z art. 40 ustawy o refundacji poprzez jego niezastosowanie oraz brak analizy możliwości jego zastosowania, art. 39 ustawy o refundacji w zw. z art. 2 pkt 26 Prawa farmaceutycznego poprzez uznanie, że lek posiada ważne pozwolenie na dopuszczenie do obrotu, art. 8 k.p.a. poprzez prowadzenie postępowania w sposób naruszający zasadę pogłębiania zaufania uczestników postępowania do władzy publicznej, jak również art. $2 \mathrm{w}$ zw. $\mathrm{z}$ art. 7 oraz art. 32 Konstytucji RP polegające na nierealizowaniu zasad państwa prawa i zasady sprawiedliwości społecznej, art. 68 ust. $1 \mathrm{w}$ zw. z ust. 3 Konstytucji RP poprzez niezapewnienie szczególnej opieki zdrowotnej dzieciom. Minister Zdrowia utrzymał decyzję odmowną, powtarzając wcześniejszą argumentację oraz podnosząc dodatkowo, że sytuacja zdrowotna małoletniego pacjenta nie może wpływać na wynik postępowania. Zdaniem Ministra Zdrowia postępowanie na podstawie art. 39 ustawy o refundacji ma charakter wnioskowy, co oznacza, że Minister Zdrowia może wydać zgodę na refundację, natomiast nie jest do tego zobowiązany. Odnosząc się do zarzutu naruszenia przepisów 
Konstytucji RP, Minister Zdrowia wskazał, że zgodnie z aktualnym stanem prawnym brak jest możliwości wydania zgody na refundację przedmiotowego leku, ponieważ warunki i zakres świadczeń zdrowotnych określa ustawa o refundacji, a zatem bezcelowe jest powoływanie się bezpośrednio na normy konstytucyjne.

Od powyższej decyzji wnioskodawcy złożyli skargę do Wojewódzkiego Sądu Administracyjnego (dalej „WSA”), wnosząc o uchylenie decyzji wydanych w obu instancjach, powołując się na wcześniej przedstawione zarzuty. Ponadto wnioskodawcy wnieśli o przedstawienie przez przedmiotowy sąd pytania prawnego Trybunałowi Konstytucyjnemu w sprawie zgodności art. 39 ust. 1 ustawy o refundacji $z$ art. 2, art. 68 ust. 1 i 3 oraz art. 68 ust. 2 w zw. $z$ art. 32 Konstytucji RP. Minister w odpowiedzi na skargę podtrzymał dotychczasowego stanowisko.

WSA, uchylając powyższe decyzje, w uzasadnieniu wskazał, że organ dokonał błędnej wykładni prawa poprzez uznanie, że art. 39 ust. 1 ustawy o refundacji nie daje podstaw do refundacji spornego produktu leczniczego, ponieważ przepis ten nie dotyczy leków posiadających pozwolenie na dopuszczenie do obrotu na terenie RP. Zdaniem sądu, mając na uwadze, fakt, że sporny lek nie wypełnia kryteriów z art. 10 ust. 1 ustawy o refundacji, analiza obowiązujących przepisów prowadzi do wniosku, że niemożliwym jest, by osoba fizyczna dochodziła refundacji takiego leku, bowiem tryb wnioskowy przewidziany jest jedynie dla wnioskodawców w rozumieniu art. 2 pkt 27 ustawy o refundacji, tj. dla podmiotu odpowiedzialnego, przedstawiciela podmiotu odpowiedzialnego, podmiotu uprawnionego do importu równoległego w prawie farmaceutycznym, wytwórcy wyrobów medycznych, jego autoryzowanego przedstawiciela, dystrybutora albo importera, w rozumieniu ustawy z dnia 20 maja 2010 r. o wyrobach medycznych (Dz. U. z 2015 r. poz. 876 i 1918 oraz z 2016 r. poz. 542), a także podmiotu działającego na rynku spożywczym. Sąd wskazał, że taka wykładnia przepisu prowadziłaby nieuchronnie do sytuacji, w której nie zostałby zapewniony równy dla wszystkich podmiotów dostęp do refundacji. W przypadku produktów leczniczych, takich jak sporny, które można zbiorczo określić mianem „sierocych”, nierzadko zdarza się, że żaden z przedstawicieli grupy wnioskodawców z art. 2 pkt 27 ustawy o refundacji nie jest 
zainteresowany ubieganiem się o refundację takiego leku, co wynika z ekonomicznej nieopłacalności takiego przedsięwzięcia. W takiej sytuacji osobie fizycznej nie przysługują żadne środki prawne do wszczęcia postępowania refundacyjnego. WSA przypomniał, iż zgodnie z art. 68 ust. 1 Konstytucji RP jednostce przysługuje prawo do ochrony zdrowia, a zgodnie $\mathrm{z}$ art. 68 ust. 2 prawo do równego dostępu do świadczeń zdrowotnych i uprawnienia te powinny być respektowane i realizowane przez system refundacji produktów leczniczych. Co więcej, dostępność do systemu ma mieć charakter rzeczywisty, a nie jedynie formalny. W związku z powyższym WSA wyprowadził wniosek, że przepis art. 39 ust. 1 ustawy o refundacji odnoszący się wyłącznie do leku nieposiadającego pozwolenia na dopuszczenie do obrotu jest wewnętrznie sprzeczny, ponieważ, zgodnie z jego literalnym brzmieniem, uniemożliwia on zastosowanie go w odniesieniu do leków posiadających takie pozwolenie uregulowanych w art. 4 ust. 9 Prawa farmaceutycznego. Sąd wskazał, że „normy z obu przepisów należy interpretować jako normy uzupełniające się, poszerzające katalog sytuacji, w których możliwe jest zastosowanie art. 39 ust. 1 ustawy o refundacji”. WSA wskazał, że wykładnia dokonana przez Ministra Zdrowia była nielogiczna, podobnie jak wnioski, które w związku z tym wyprowadzono i opowiedział się za koniecznością zastosowania w przedmiotowej sprawie wykładni systemowej i celowościowej.

Na rozstrzygnięcie WSA Minister Zdrowia wniósł skargę kasacyjną, zarzucając wyrokowi naruszenie zarówno przepisów postępowania, które mogły mieć istotny wpływ na wynik sprawy, jak i prawa materialnego. Ponadto do toczącego się przed NSA postępowania swój udział zgłosił Rzecznik Praw Obywatelskich (dalej: „RPO”).

\section{STANOWISKO ZAPREZENTOWANE PRZEZ NSA}

NSA oddalił skargę kasacyjną Ministra Zdrowia. W uzasadnieniu do orzeczenia NSA zdefiniował jako główne zagadnienie, które podlegało rozstrzygnięciu i które zarazem legło u podstaw wszystkich zarzutów kasacyjnych, kwestię dotyczącą „prawidłowości przyjęcia, że w trybie art. 
39 ust. 1 Ustawy o refundacji organ uprawniony jest do wydania zgody na refundację leku sprowadzonego z zagranicy na warunkach i w trybie określonym w art. $4 \mathrm{PF}$, posiadającego zezwolenie na dopuszczenie do obrotu na terytorium Rzeczpospolitej Polskiej”. NSA podzielił stanowisko WSA, stwierdzając, że art. 39 ust. 1 ustawy o refundacji należy interpretować w ten sposób, że „ma on zastosowanie nie tylko w przypadku leku nieposiadającego pozwolenia na dopuszczenie do obrotu, ale przez odwołanie do art. 4 również ust. 9 PF w zw. $\mathrm{z}$ art. 68 ust. 1 i 2 Konstytucji RP, [ale, że] ma on zastosowanie także w przypadku leku posiadającego pozwolenie na dopuszczenie do obrotu, jeżeli spełnione są warunki unormowane w tym ustępie”. Do powyższych wniosków NSA doszedł, kierując się wykładnią systemową, celowościową i prokonstytucyjną. NSA podkreślił, że tylko taka wykładnia art. 39 ust. 1 ustawy o refundacji pozwala na zapewnienie rzeczywistej dostępności do systemu refundacji i zadośćuczynienie wymogom art. 68 ust. 1 i 2 Konstytucji RP. Ponadto, wskazał na konieczność i zarazem obowiązek organów w zakresie dokonywania wykładni przepisów stosowanych w konkretnej sprawie „Z uwzględnieniem wartości i zasad wynikających z przepisów Konstytucji”. Jednocześnie, NSA powołał się na pogląd Sądu Najwyższego wyrażony w postanowieniu z 13 stycznia 2016 r., o sygn. akt V CSK 455/15, mianowicie, jeżeli „treść przepisu ustalona na podstawie dyrektyw I stopnia (językowej, systemowej i celowościowej) jest rozbieżna lub budzi wątpliwości co do zgodności z aktualną aksjologią, sądy powinny stosować generalne dyrektywy wykładni stanowiące metanormy II stopnia”. NSA wskazał, że w sprawach dotyczących refundacji należy mieć na uwadze zgodność ewentualnych rozstrzygnięć z art. 68 w zw. z art. 30 i art. 38 Konstytucji RP. W uzasadnieniu NSA odniósł się również do kwestii szczególnego postępowania organów w sprawach dotyczących prawa do ochrony życia, które z sposób immanentny powiązane jest z godnością osoby ludzkiej. NSA przywołał odnośnie do tej kwestii przyjętą w doktrynie i orzecznictwie dyrektywę interpretacyjną in dubio pro vita humana, która zobowiązuje wszelkie możliwe wątpliwości co do ochrony życia ludzkiego rozstrzygać na rzecz tej ochrony. Ponadto, NSA podkreślił, że w przedmiotowej sprawie, zgodnie $\mathrm{z}$ art. 68 ust. 3 Konstytucji RP, wnioskującemu o refundację 
leku powinna zostać udzielona ochrona szczególna z uwagi na fakt, że jest on dzieckiem.

\section{Komentarz do stanowiska NSA}

Autor w pełni zgadza się z glosowanym wyrokiem. NSA słusznie zastosował wykładnię systemową, celowościową i prokonstytucyjną art. 39 Ustawy o refundacji. W wielu analogicznych postępowaniach Minister Zdrowia wskazuje, że zgodnie z zasadą clara non sunt interpretanda przepis art. 39 ust. 1 Ustawy o refundacji, $z$ uwagi na swe jednoznaczne brzmienie, nie wymaga interpretacji. Jest to twierdzenie całkowicie niezasadne, na co wskazuje liczne orzecznictwo dot. powyższego przepisu. Sam fakt, że istnieje rozbieżne orzecznictwo w tym przedmiocie oznacza, że art. 39 jest przepisem niejasnym i w związku z tym wymaga interpretacji oraz posłużenia się innymi niż literalna rodzajami wykładni. Poza tym przywołana wcześniej zasada clara non sunt interpretanda nie jest aktualnie powszechnie akceptowana ani w doktrynie, ani też w orzecznictwie sądów administracyjnych ${ }^{1}$. Zgodnie z ogólną zasadą interpretacji tekstów prawnych, jeżeli dosłowna wykładnia art. 39 Ustawy o refundacji prowadzi do nielogicznej konkluzji, wówczas należy zastosować interpretację celowościową. Wykładnia celowościowa prowadzi do wniosku, że omawiany mechanizm refundacji jest specyficzny dla produktów, którymi obrót w Polsce nie jest automatycznie dozwolony i dlatego wymagają one specjalnego pozwolenia zgodnie $\mathrm{z}$ art. 4 Prawa farmaceutycznego.

Zauważyć należy, że proponowana przez Ministra Zdrowia wykładnia przepisów Ustawy o refundacji powoduje pozbawienie pewnej grupy pacjentów - ubezpieczonych - możliwości realizacji swojego prawa do ochrony zdrowia, bowiem z góry odmawia się jej dostępu do leku refundowanego ze względów niedotyczących procesu leczenia i aspektów medycznych, lecz ze względu na formalistyczną wykładnię związaną

\footnotetext{
1 Wyrok NSA w Warszawie z 21 maja 2014 r., o sygn. akt I OSK 585/13, http:// orzeczenia.nsa.gov.pl/doc/460489F7FA, dostęp 15 lutego 2017 r.
} 
ze statusem potrzebnego dla nich leku. Stoi to w sprzeczności z treścią art. 68 ust. 1-3 Konstytucji RP. Przepis ten nie zawiera ograniczenia co do populacji, której prawo do ochrony zdrowia oraz równe prawo do świadczeń zdrowotnych finansowanych ze środków publicznych przysługują. Wręcz przeciwnie, przepisy te gwarantują prawo do ochrony zdrowia wszystkim, zaś prawo do świadczeń finansowanych ze środków publicznych - na zasadzie równego dostępu. Wykluczenie a priori pewnej kategorii ubezpieczonych, i to dzieci szczególnie chronionych ust. 3 art. 68 Konstytucji RP, jest niezgodne z tymi zasadami, zwłaszcza gdy nie dotyczy to medycznych aspektów terapii, lecz formalistycznych wymogów rejestracyjnych leku. W swoim orzecznictwie Trybunał Konstytucyjny wyraźnie podkreślił, że prawo do ochrony zdrowia nie może być traktowane jako uprawnienie iluzoryczne bądź czysto potencjalne².

NSA słusznie zauważył, że organ powinien kierować się przede wszystkim zasadami wyrażonymi w Konstytucji RP. Zgodnie z uchwałą NSA z dnia 10 stycznia 2011 r., o sygn. akt: I OPS 4/10, „interpretując normy prawne, należy mieć na względzie przede wszystkim zasady konstytucyjne. W sytuacji niejednoznacznego brzmienia przepisu, kiedy wykładnia językowa może prowadzić do rozbieżnych wniosków, konieczne jest poszukiwanie interpretacji, która pozwoli na uzgodnienie treści przepisu z Konstytucją". Podobnie NSA w innej uchwale z dnia 13 listopada 2012 r., o sygn. akt: II OPS 2/12: „tak zwana prokonstytucyjna interpretacja prawa jest jednym z rodzajów wykładni systemowej. Oznacza to, że błędne byłoby ograniczanie wykładni systemowej wyłącznie do ustawy, z której pochodzi interpretowany przepis, lub do innych ustaw regulujących daną dziedzinę prawa. Koniecznym elementem tego typu wykładni jest uwzględnienie również regulacji konstytucyjnych. Ponadto, z uwagi na zasadę nadrzędności Konstytucji, wykładnia prokonstytucyjna powinna mieć pierwszeństwo przed wykładnią funkcjonalną i celowościową, a także wykładnią systemową wewnętrzną". O wykładni prokonstytucyjnej wypowiedział się również Trybunał

2 Wyrok Trybunału Konstytucyjnego z 7 stycznia 2004 r., sygn. akt K 14/03, http:// ipo.trybunal.gov.pl/ipo/Sprawa?\&pokaz=dokumenty\&sygnatura=K\%2014/03, dostęp 15 lutego 2017 r. 
Konstytucyjny. W wyroku z dnia 28 czerwca 2000 r., o sygn. akt K 25/99, Trybunał wskazał, że pomimo iż językowe znaczenie tekstu stanowi granicę wykładni, tzn. nie można posługiwać się wykładnią funkcjonalną, jeżeli wykładnia językowa prowadzi do jednoznaczności tekstu, to nie jest to granica bezwzględna.Zdaniem Trybunału przekroczenie tej granicy musi mieć „silne uzasadnienie aksjologiczne, odwołujące się przede wszystkim do wartości konstytucyjnych”. Wartością konstytucyjna, do której odwołuje się tutaj NSA, jest ochrona zdrowia wyrażona w art. 68 Konstytucji RP.Oczywiście wykładnia zastosowana przez NSA w poniższej sprawie jest niewątpliwie wykładnią twórczą, ponieważ w oczywisty sposób wykracza poza literalny sens art. 39 Ustawy o refundacji. Pomimo że w naszym kraju, jak i w innych krajach należących do rodziny civil law obowiązuje generalny zakaz wykładni prawotwórczej, tj. sądom nie wolno tworzyć prawa ${ }^{3}$, to zgodnie $z$ doktryną oraz orzecznictwem istnieją od tego pewne odstępstwa. Lech Morawski wskazuje przykładowo, że wykładnia twórcza jest dopuszczalna, gdy wykładnia językowa jest rażąco sprzeczna $z$ Konstytucją RP lub zasadami sprawiedliwości społecznej ${ }^{4}$. Pogląd ten jest zresztą zbieżny z powołanym wcześniej orzeczeniem Trybunału Konstytucyjnego. Co więcej, niektórzy autorzy twierdzą, że istnieją sytuacje, w których prawo wręcz zobowiązuje organy publiczne do odstąpienia od literalnej wykładni przepisu $^{5}$. Analizując uzasadnienie glosowanego wyroku, należy z całą stanowczością stwierdzić, że interpretacja zastosowana przez NSA jest silnie uzasadniona aksjologicznie, ponieważ, jak już wskazano wcześniej, literalna wykładnia art. 39 Ustawy o refundacji odbiera pewnej grupie pacjentów, w tym przypadku skarżącemu, prawo do ochrony zdrowia. Odmowa refundacji stanowi zaś realne zagrożenie dla jego życia i zdrowia.

Głosowany wyrok bez wątpienia nie kończy sporu o wykładnię art. 39 Ustawy o refundacji. Wręcz przeciwnie, jest pierwszym wyrokiem, w którym NSA bezpośrednio stwierdza, że refundacja na podstawie

\footnotetext{
3 L. Morawski, Zasady wykładni prawa², Toruń 2010, s. 21.

4 Ibidem.

5 R. Kijowski, J. RadwanowiCz-WANCZEWsKa, Wykładnia i stosowanie prawa administracyjnego, IV. «Lex/el.» $2012 \mathrm{r}$.
} 
art. 39 odnosi się również do leków posiadających centralne pozwolenie na dopuszczenie do obrotu. Warto wskazać, że w uzasadnieniu do wyroku, NSA bezpośrednio stwierdza, że nie zgadza się z innym wyrokiem NSA z dnia 25 września 2015 r. o sygn. akt II GSK1856/14. Pomimo tożsamego stanu faktycznego NSA w powyższym wyroku stwierdził, że brzmienie art. 39 ustawy o refundacji wyklucza możliwość refundacji leków posiadających centralne pozwolenie na dopuszczenie do obrotu. Na marginesie można jedynie wskazać, że w uzasadnieniu powyższego wyroku NSA ogranicza się właściwie do przedstawionego sformułowania, bez odwoływania się do wykładni konstytucyjnej czy celowościowej. Owszem, w przestrzeni prawnej są jeszcze trzy inne wyroki NSA, dotyczące wykładni art. 39 Ustawy o refundacji, niewskazujące jednak bezpośrednio, która $\mathrm{z}$ wykładni powyższego przepisu jest właściwa, a odnoszące się bardziej do naruszenia zasad postępowania administracyjnego, niż prawa materialnego ${ }^{6}$. Oznacza to, że obecnie mamy dwa całkowicie sprzeczne ze sobą wyroki NSA. Brak jednolitej linii orzeczniczej jest również widoczny w wyrokach Wojewódzkich Sądów Administracyjnych. W bazie orzeczeń sądów administracyjnych ${ }^{7}$ widnieje kilkadziesiąt wyroków dotyczących tożsamych stanów faktycznych, w tym jedna połowa jest zbieżna $\mathrm{z}$ glosowanym wyrokiem, natomiast druga nie. Konsekwencją tych rozbieżności jest z jednej strony niepewność pacjentów co do refundacji ich leków, natomiast z drugiej strony Minister Zdrowia nie ma jasnego sygnału, jakie decyzje powinien wydawać.

Rozwiązaniem tej sytuacji mogłaby być tzw. „abstrakcyjna” uchwała NSA, o której mowa w art. $15 \$ 1$ pkt. $2^{8}$ ustawy z dnia 30 sierpnia $2002 \mathrm{r}$. Prawo o postępowaniu przed sądami administracyjnymi (dalej: „PPSA”), w której NSA jasno wskazałby, jak należy intepretować art. 39 Ustawy

6 Wyrok NSA w Warszawie z 21 kwietnia 2016 r., o sygn. akt II GSK 2654/14, wyrok NSA w Warszawie z 17 września 2015 r. o sygn. akt II GSK 1414/15, Wyrok NSA w Warszawie z 17 września 2015 r., o sygn. akt II GSK 1415/15.

7 Baza dostępna na stronie internetowej http://orzeczenia.nsa.gov.pl/.

8 „\$1. Naczelny Sąd Administracyjny: 2) podejmuje uchwały mające na celu wyjaśnienie przepisów prawnych, których stosowanie wywołało rozbieżności w orzecznictwie sądów administracyjnych”. 
o refundacji. Pomimo, że tego rodzaju uchwały nie są bezpośrednio wiążące w żadnej sprawie sądowoadministracyjnej, to ich pośredni wpływ jest znaczący. Zgodnie z art. 269 PPSA, jeżeli jakikolwiek skład sądu administracyjnego rozpoznający sprawę nie podziela stanowiska zajętego w uchwale składu siedmiu sędziów, całej Izby albo w uchwale pełnego składu NSA, przedstawia powstałe zagadnienie prawne do rozstrzygnięcia odpowiedniemu składowi. Oznacza to, że uchwały te powinny być respektowane przez sądy administracyjne, dopóki nie nastąpi ich zmiana w trybie art. 269 PPSA $^{9}$.

Glosa aprobująca do WYroku NaCZelnego SĄDU ADMINISTRACYJNEGO Z DNIA 6 PAŹDZIERNIKA 2016 R.

O SYGN. AKT II GSK 2765/16

\section{Streszczenie}

Glosowany wyrok Naczelnego Sądu Administracyjnego dotyczy refundacji leków posiadających tzw. centralne pozwolenie na dopuszczenie sprowadzanych $\mathrm{w}$ trybie importu docelowego. W przedmiotowym orzeczeniu, Sąd stwierdził, że wbrew literalnej wykładni art. 39 ustawy z dnia 12 maja 2011 r. o refundacji leków, środków spożywczych specjalnego przeznaczenia żywieniowego oraz wyrobów medycznych (Dz.U. z 2016 r. poz. 1536) możliwa jest refundacja leków posiadających centralne pozwolenie na dopuszczenie do obrotu.Autor w pełni zgadza się z glosowanym wyrokiem, w szczególności wskazując na zasadność stosowania prokonstytucyjnej wykładni przepisów związanych z refundacją leków.

\footnotetext{
9 T. Woś, Prawo o postępowaniu przed sądami administracyjnymi. Komentarz ${ }^{6}$, Wolters Kluwer/el/., 2016 r.
} 
A GLOSS IN APPROVAL OF JUDGEMENT II GSK 2765/16 ISSUED BY THE Polish Supreme Aministrative Court on 6 october 2016

\section{Summary}

The Supreme Administrative Court judgement which is glossed in this article concerns reimbursement due to a patient for medications not normally available in Poland on a reimbursed prescription but admitted in special cases as an individual (targeted) import on the grounds of a central permit. In this judgement the Court ruled that contrary to the literal interpretation of Art. 39 of the Reimbursement for Medications, Special-Purpose Foodstuffs, and Medical Products of 12 May 2011 (Ustawa z dnia 12 maja 2011 r. o refundacji leków, środków spożywczych specjalnego przeznaczenia żywieniowego oraz wyrobów medycznych; Dziennik Ustaw 2016, Item 1536), patients who have a central permit admitting a medication they are taking for individual (targeted) import can claim a reimbursement for their expenses incurred due to the import of the medication. I fully agree with this ruling, especially as it takes a pro-constitutional approach to the interpretation of the provisions on reimbursed medications.

Słowa kluczowe: refundacja; prawo farmaceutyczne; centralne pozwolenie na dopuszczenie do obrotu; pozwolenie na dopuszczenie do obrotu; leki sieroce, choroby rzadkie.

Keywords: reimbursement; pharmaceutical law; central marketing authorization; marketing authorization; orphan drugs; rare diseases.

\section{Literatura:}

Woś T., Prawo o postępowaniu przed sadami administracyjnymi. Komentarz, Wolters Kluwer/el/., $2016 \mathrm{r}$.

KIJOWSKI R., RADWANOWICZ-WANCZEWSKa J., Wykładnia i stosowanie prawa administracyjnego, IV. «Lex/el.» $2012 \mathrm{r}$.

Morawski L., Zasady wykładni prawa, Towarzystwo Naukowe Organizacji i Kierownictwa, Torun 2010 r. 